\title{
Family Structure, Parental Monitoring and Marijuana Use among Adolescents in Jamaica: Findings from Nationally Representative Data
}

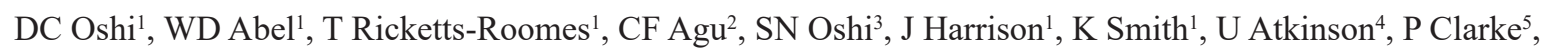 \\ P Whitehorne-Smith ${ }^{1}, \mathrm{KN}^{3}$ Ukwaja $^{6}$
}

\begin{abstract}
Objective: Marijuana misuse by adolescents is a social and public mental health problem in Jamaica and globally. Research has suggested that family structure is one of the factors that influences adolescents' consumption of marijuana. This study was undertaken to determine if family structure and parental monitoring had any association with marijuana use among adolescents in Jamaica.

Methods: Data from a nationally representative sample collected in Jamaica's National Secondary School Survey 2013 were analysed. The study sample consisted of 3365 grades 8-12 students from 38 secondary schools. Descriptive and inferential statistics were computed using PSPP software.

Results: A significantly higher proportion of male (24.4\%) than female (16.9\%) adolescents reported lifetime use of marijuana. There was no significant difference in the proportions of male and female adolescents regarding marijuana use over the past one year (15.5\% versus $10.4 \%)$ or over the past 30 days (8.7\% versus $5.4 \%)$. There were significant differences in lifetime use of marijuana among adolescents from different family structures (Chi-square = 442.63, $\mathrm{p}=0.00)$. The differences were not between one-parent families and two-parent families. Parental monitoring of adolescents'school work was strongly protective against lifetime marijuana use. Adolescents whose parents paid attention very closely (adjusted odds ratio [AOR]: 0.34; 95\% confidence intervals [95\% CI]: 0.22, 0.52), closely (AOR: 0.49; 95\% CI: $0.32,0.99)$ and somewhat closely (AOR: 0.63; 95\% CI: 0.41, 0.99) to what they did at school were all significantly less likely to have ever used marijuana.

Conclusion: Lifetime marijuana use among adolescents was associated with family structure but not from the perspective of one-parent families versus two-parent families. Parental monitoring of adolescents'school activities significantly protected against lifetime use of marijuana.
\end{abstract}

Keywords: Adolescents, family structure, Jamaica, marijuana use, parental monitoring, youth

From: ${ }^{1}$ Department of Community Health and Psychiatry, The University of the West Indies, Mona, Jamaica, West Indies, ${ }^{2}$ School of Nursing, The University of the West Indies, Mona, Jamaica, West Indies, ${ }^{3}$ Faculty of Social and Behavioural Sciences, International University of the Caribbean, Kingston, Jamaica, West Indies, ${ }^{4}$ National Council on Drug Abuse, Kingston, Jamaica, West Indies, ${ }^{5}$ Inter-American Drug Abuse Control Commission, Secretariat for Multidimensional Security, Organization of American States, Washington, DC, United States of America and ${ }^{6}$ Department of Internal Medicine, Federal Teaching Hospital, Abakaliki, Nigeria.

Correspondence: Dr D Oshi, Department of Community Health and Psychiatry, The University of the West Indies, Mona, Kingston 7, Jamaica, West Indies. Email: dannyoshi@yahoo.com 


\title{
La Estructura Familiar, la Vigilancia Parental y el Consumo de Marihuana entre los Adolescentes en Jamaica: Resultados de Datos Representativos a Nivel Nacional
}

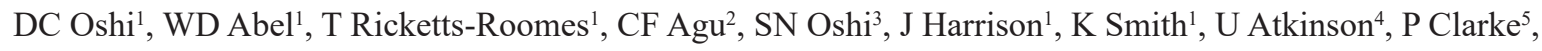
P Whitehorne-Smith ${ }^{1}, \mathrm{KN}^{3}$ Ukwaja $^{6}$

\begin{abstract}
RESUMEN
Objetivo: El uso indebido de la marihuana por los adolescentes es un problema de salud mental social y pública en Jamaica y en todo el mundo. Las investigaciones sugieren que la estructura familiar es uno de los factores que influyen en el consumo de marihuana de los adolescentes. Este estudio se emprendió para determinar si la estructura familiar y la vigilancia parental tenían alguna asociación con el consumo de marihuana entre los adolescentes en Jamaica.

Métodos: Se analizaron los datos de una muestra representativa nacional recogida en la Encuesta Nacional de la Escuela Secundaria de Jamaica en 2013. La muestra del estudio consistió en 3365 estudiantes de los grados 8-12 de 38 escuelas secundarias. Las estadísticas descriptivas e inferenciales fueron computadas utilizando el software PSPP.

Resultados: Una proporción significativamente mayor de adolescentes varones (24.4\%) que de hembras (16.9\%) reportó haber usado marihuana toda su vida. No hubo diferencias significativas en las proporciones de adolescentes varones y hembras en relación con el consumo de marihuana durante el último año (15.5\% versus $10.4 \%$ ) o en los últimos 30 días $(8.7 \%$ versus 5.4\%). Hubo diferencias significativas en el uso crónico de la marihuana entre los adolescentes de diferentes estructuras familiares (Chi-square $=442.63, \mathrm{p}=0.00)$. No hubo diferencias entre familias monoparentales y familias biparentales. La supervisión parental del trabajo de la escuela de los adolescentes fue un fuerte factor de protección contra el uso crónico de la marihuana. Los adolescentes cuyos padres prestaban atención muy de cerca (odds ratio ajustado [AOR]: 0.34; intervalos de confianza del 95\% [95\% IC]: 0.22, 0.52), de cerca (AOR: 0.49; 95\% IC: 0.32, 0.99) y algo de cerca (AOR: 0.63; 95\% IC: 0.41, 0.99) a lo que ellos hacian en la escuela, presentaban todos una probabilidad significativamente menor de haber usado marihuana alguna vez en su vida.

Conclusión: El consumo crónico de marihuana entre los adolescentes se asoció con la estructura familiar, pero no desde la perspectiva de las familias monoparentales frente a las familias biparentales. La vigilancia parental de las actividades escolares de los adolescentes representó una protección significativa frente al uso crónico de la marihuana.
\end{abstract}

Palabras claves: Adolescentes, estructura familiar, Jamaica, consumo de marihuana, supervisión parental, juventud

\section{West Indian Med J 2017; 66 (5): 537}

\section{INTRODUCTION}

Marijuana use by adolescents is a global social and mental health issue, with an estimated $55 \%$ of adolescents using marijuana at least once in their lifetime (1). Therefore, marijuana is one of the most commonly used drugs by adolescents worldwide (2). Significant gender differences have also been reported with male adolescents having a higher prevalence than female adolescents $(3,4)$. Studies have shown that adolescents who initiate marijuana use may carry it through to adulthood and furthermore that lifetime use of marijuana is higher than past-year use and than past-month use (5-9). This suggests that some adolescents have been able to discontinue marijuana use after having initiated the habit.

In the Caribbean, studies have shown that adolescent use of marijuana is also high. Among older adolescents/ youths in the universities in Trinidad and Tobago, 13\% reported having used marijuana in the past six months with 55\% stating that they used the drug fewer than three times per month (10). Similarly, in Jamaica, a body of 
evidence has revealed that marijuana use is relatively high among adolescents and young persons $(9,11)$. Research has shown that the lifetime use of marijuana among adolescents was $20.7 \%$ in 2013 , a slight decline from $21.5 \%$ in $2006(9,11)$.

Consequent upon adverse life outcomes associated with marijuana use, researchers have made efforts to understand factors that may be associated with marijuana use among adolescents. Among the factors that have attracted the attention of researchers from the 1990s has been the role that family structure plays in adolescents' initiation and consumption of marijuana. In the United Kingdom and France, adolescents from one-parent families and restructured families (one biological parent and one step-parent) were found to have a higher risk of using marijuana than adolescents from families with two biological parents (3).

Children growing up with one parent have also been stated to have had increased risks of illicit drugs-related diseases $(12,13)$. Accordingly, adolescents living with one parent were found to use marijuana, inhalation drugs and amphetamine much more significantly compared to those residing with both parents (14). Among them, children being raised by fathers only were significantly more likely to use marijuana than children in mother-only or two-parent families. On the contrary, Mather argued that children from mother-only families had higher risks of drug abuse than those from two-parent or father-only families (15). Whether adolescents use marijuana or not might have to do with the social influence exerted on them by their parents, which might in turn help them in gaining self-control. Researchers have also posited that lone parents seem unable to exert this social influence and, therefore, children growing up in such families demonstrate less self-control compared to those from two-parent families (16). There is also evidence that growing up in families in which the parents have separated or divorced is an adverse childhood experience, which has negative effects on the general and mental health of children (17).

More recent data investigating the association between family structure and adolescents' use of marijuana are scarce, especially with reference to the Caribbean. This is despite the changing family dynamics in the region where it has been noted that there is a high prevalence of one-parent families (18). Indeed, oneparent families have increased from comprising $40 \%$ of Jamaican families in 1996 to accounting for $45 \%$ of the families in 2011, and most of the one-parent families are of the mother-only type $(19,20)$.
Irrespective of the type of family structure, studies suggest that parental monitoring of children potentially protects them against commencing marijuana consumption (21). Interestingly, parents' discussing the dangers of drug abuse has been shown as ineffective in lowering the risks of initiating marijuana use (22).

This study was therefore undertaken to determine if family structure and parental monitoring had any association with marijuana use among adolescents in Jamaica. The study was made even more imperative with the increasing prevalence of one-parent families in Jamaica.

\section{SUBJECTS AND METHODS}

The study involved analysis of secondary data which were collected from Jamaica's National Secondary School Survey 2013 (NSSS) and were nationally representative. The NSSS was conducted at 38 secondary schools randomly drawn from a list of all secondary schools in the country. The sample consisted of 3365 grades $8-12$ students $(9,11)$. The NSSS was funded by the Inter-American Drug Abuse Control Commission, Organization of American States, United States of America (USA), to improve drug surveillance among its member states.

The key independent variable was parents'/guardians' marital status, which was used in this study as the proxy indicator/variable for family structure. To show clearly any differences in proportions among the various family types, the researchers decided to allow the different one-parent family types (single, divorced, separated and widowed) to remain as individual entities. 'Single' refers to a parent that never married; 'divorced' refers to a parent who had been married and was not remarried by the time of the survey; 'separated' refers to a previously married parent who was separated from the spouse but not living together with another partner (ie not in a common law marriage); and 'widowed' refers to a parent who had lost his or her married partner by death and was not remarried or living together with another partner (ie not in a common law marriage) at the time of survey. The 'married' family structure in this research was used as a variable that comprised nuclear family types, categorized as 'intact' (where both biological parents were present) and 'restructured' (where one biological parent and one step-parent were present) families (3). 'Living together/common law' denotes the family strucutre in which parents (either both biological parents or one biological parent and one step-parent) lived together but were not legally married. Covariates were also analysed. These included 'parental 
monitoring', which was assessed with the following questions:

- How closely parent pays attention to student's (subject's) school work? Response options were: 1 $=$ very closely, $2=$ closely, $3=$ somewhat and $4=$ not at all.

- Parent controls the time the subject comes in at night. Responses options were: $1=$ yes, $2=$ no, $3=$ rarely and $4=$ never.

- How often parent knows subject's whereabouts? Response options were: $1=$ never, $2=$ sometimes and $3=$ always.

The independent variable 'Parent discusses with subject about dangers of drugs' had two response options: $1=$ yes and $2=$ no.

Prevalence of lifetime marijuana use was assessed with a question on whether the participant had ever used the drug. Response options were: $1=$ yes and $2=$ no. Other dependent variables were:

- Have you ever smoked marijuana at least once over the past 12 months? Response options were: $1=$ yes and $2=$ no.

- How often have you smoked marijuana? The five response options were: 1 = just once, $2=$ several times over the past 12 months, $3=$ several times a month, $4=$ several times a week, and $5=$ every day. However, only the first three response options were used in our analysis because the figures in the remaining two were low and gave invalid results in logistic regression analysis.

- Have you smoked marijuana once over the past 30 days? Response options were: $1=$ yes and $2=$ no.

Descriptive analyses were computed for the social and demographic characteristics of the participants. In bivariate analysis, differences in proportions of participants with different characteristics were computed and significance tested with Chi-square. Significance level was set at $p<0.05$. Multivariate analysis was done using binary logistic regression. Crude odds ratio (COR), adjusted odds ratio (AOR) and 95\% confidence intervals $(95 \% \mathrm{CI})$ were computed to assess if independent variables were risk or protective factors regarding three key dependent variables: 'lifetime use of marijuana', 'marijuana use over past 12 months' and 'marijuana use over past three months'. We believed that factors which would affect these three levels/aspects of adolescent marijuana use would most likely also affect other frequencies of marijuana use (eg 'just once', 'several times in the past
12 months', 'several times in a month'); therefore, we did not conduct logistic regression using these variables listed in the brackets as dependent variables. All statistical analyses were done using PSPP software (GNU Project).

The NSSS was approved by Jamaica's Ministry of Health and implemented in line with international best practices (9).

\section{RESULTS}

The mean age of the subjects was 14.97 years (standard deviation: 1.71 years). Out of the 3365 subjects, $42.4 \%$ were male compared to $56.2 \%$ who were female (Table 1). By family structure, subjects from single-parent (never married) families accounted for the highest proportion $(31.0 \%)$, followed by subjects from married-parents families $(27.6 \%)$. The lowest proportion of subjects came from widowed-parent families (1.4\%). Subjects from public secondary schools constituted $97.9 \%$, compared to $2.1 \%$ who were from private secondary schools (Table 1).

Regarding the association between gender and marijuana use (not shown in Tables), lifetime use of marijuana differed significantly by gender, with $24.4 \%$ of male subjects versus $16.9 \%$ of female subjects reporting having ever used marijuana. On the contrary, 194 male

Table 1: Distribution of key sociodemographic characteristics of the subjects in the National Secondary School Survey 2013, Jamaica $(\mathrm{n}=3365)$

\begin{tabular}{llll}
\hline Characteristics & & n & \%* \\
\hline $\begin{array}{l}\text { Age } \\
\text { (mean, standard deviation) }\end{array}$ & 14.97 years, 1.71 years & & \\
Gender** & Male & 1426 & 42.4 \\
& Female & 1915 & 56.2 \\
Family structure** & Single & & \\
& Married & 1044 & 31 \\
& Divorced & 928 & 27.6 \\
& Separated & 101 & 3 \\
& Widowed & 576 & 17.1 \\
& Common law & 48 & 1.4 \\
& (living together) & 477 & 14.2 \\
& Other & 122 & 3.6 \\
& & & \\
Type of school & Public & 3295 & 97.9 \\
& Private & 70 & 2.1 \\
\hline
\end{tabular}

* Percentages may not add up to 100 due to rounding.

** Missing data: gender (24 subjects) and family structure (69 subjects). 
adolescents (15.5\%) had used marijuana at least once in the past 12 months, compared to 185 female adolescents (10.4\%). Similarly, 108 male subjects (8.7\%) had used marijuana at least once in the past 30 days, compared to 97 female subjects (5.4\%). Thus, there was no significant difference between male and female adolescents in their past-12-month use or past-30-day use of marijuana. This pattern was also similar to the findings for the marijuana use of 'just once', 'several times in the past 12 months' and 'several times a month'.

Table 2 displays the prevalence of marijuana use according to the family structure of the adolescents. Significant differences existed in the proportion of adolescents from the different family structures in terms of their use of marijuana. Specifically, 215 adolescents (20.6\%) from single-parent families reported having ever used marijuana, compared to 124 adolescents (13.4\%) from married-parents families, $13.9 \%$ from divorced-parent families and 25\% from widowed-parent families. There was no significant difference in the past-12-month use contrary to what was observed for marijuana use over the past 30 days among adolescents from the different family structures. Similarly, no significant differences were observed in the proportion of adolescents from the different family structures in their frequency of use of marijuana.

As shown in Table 3, in the multivariate analysis of determinants of lifetime use of marijuana among the adolescents, male adolescents had 1.59 times the odds of lifetime use of marijuana compared to female adolescents (COR: 1.59; 95\% CI: 1.33, 1.90), though in the presence of other predictors, this effect was weakened but remained significant (AOR: 1.28; 95\% CI: 1.05,
1.57). However, family structure was not significantly associated with lifetime use of marijuana, and none of the different types of family structure was a risk factor or protective factor for lifetime use of marijuana when the other predictor variables were controlled for. How closely parents paid attention to what the adolescents did at school was a significant factor affecting adolescents' lifetime use of marijuana. Adolescents whose parents paid attention very closely (AOR: 0.34; 95\% CI: $0.22,0.52$ ), closely (AOR: 0.49 ; 95\% CI: 0.32 , 0.99 ) and somewhat closely (AOR: 0.63 ; $95 \%$ CI: 0.41 , 0.99 ) to what they did at school were all significantly less likely to have ever used marijuana than adolescents whose parents did not pay attention at all. Instructively, adolescents whose parents did not control the time they came in at night were at a significantly greater risk of reporting lifetime use of marijuana (AOR: 2.74; 95\% CI: 1.16, 6.67), compared to those whose parents always did. Whether parents had discussed the dangers of drug abuse with the adolescents showed no significant association with lifetime use of drugs. Adolescents whose parents never knew their whereabouts (COR: 5.12; 95\% CI: $3.27,8.03)$ and those whose parents sometimes knew their whereabouts (COR: 2.38; 95\% CI: 1.94, 2.91) after school hours or on the weekends had higher risks of lifetime use of marijuana (AOR: 2.89; 95\% CI: 1.75 , 4.78 and AOR: 1.72; 95\% CI: 1.37, 2.15, respectively), compared to those whose parents always knew their whereabouts.

Table 4 displays the logistic regression results for factors associated with marijuana use over the past 12 months versus over the past 30 days. Gender was not significantly associated with marijuana use over the past

Table 2: Prevalence of marijuana use among the subjects by family structure - National Secondary School Survey 2013, Jamaica $(n=3365)$

\begin{tabular}{|c|c|c|c|c|c|c|c|c|}
\hline \multirow[b]{2}{*}{ Variables } & \multicolumn{8}{|c|}{ Family structure* } \\
\hline & $\begin{array}{l}\text { Single } \\
\text { n (\%) }\end{array}$ & $\begin{array}{c}\text { Married } \\
\text { n (\%) }\end{array}$ & $\begin{array}{c}\text { Divorced } \\
\text { n (\%) }\end{array}$ & $\begin{array}{c}\text { Separated } \\
\text { n }(\%)\end{array}$ & $\begin{array}{c}\text { Widowed } \\
\text { n (\%) }\end{array}$ & $\begin{array}{c}\text { Common law } \\
\text { n (\%) }\end{array}$ & $\begin{array}{l}\text { Other } \\
\text { n (\%) }\end{array}$ & $\begin{array}{c}\text { Chi-square } \\
(p)\end{array}$ \\
\hline Total & 1044 & 928 & 101 & 576 & 48 & 477 & 122 & \\
\hline Lifetime use of marijuana & $\begin{array}{l}215 \\
(20.6)\end{array}$ & $\begin{array}{l}124 \\
(13.4)\end{array}$ & $14(13.9)$ & $119(20.7)$ & $12(25)$ & $90(18.9)$ & $23(18.9)$ & $\begin{array}{l}442.63 \\
(0.00)\end{array}$ \\
\hline Marijuana use $\geq$ once in the past 12 months & $\begin{array}{l}138 \\
(13.2)\end{array}$ & $80(8.6)$ & $12(11.9)$ & $72(12.5)$ & $6(12.5)$ & $49(10.3)$ & $17(13.9)$ & $11.71(0.07)$ \\
\hline Marijuana use $\geq$ once in the past 30 days & $81(7.8)$ & $34(3.7)$ & $9(8.9)$ & $42(7.3)$ & $3(6.3)$ & $21(4.4)$ & $9(7.4)$ & $18.56(0.00)$ \\
\hline Frequency of marijuana use & & & & & & & & $4.99(0.55)$ \\
\hline Just once & $59(5.7)$ & $33(3.6)$ & $6(5.9)$ & $25(4.3)$ & $1(2.1)$ & $21(4.4)$ & $5(4.1)$ & \\
\hline Several times in the past 12 months & $55(5.3)$ & $28(3.0)$ & $3(3.0)$ & $33(5.8)$ & $3(6.3)$ & $22(4.6)$ & $6(4.9)$ & \\
\hline Several times a month & $18(1.7)$ & $13(1.4)$ & $1(1.0)$ & $9(1.6)$ & $0(0.0)$ & $8(1.7)$ & $2(1.6)$ & \\
\hline
\end{tabular}

* Missing data: 69 subjects.

Percentages may not add up to 100 due to rounding. 
Table 3: Factors associated with lifetime use of marijuana among adolescents in Jamaica

\begin{tabular}{|c|c|c|c|c|c|}
\hline Variables & & $\begin{array}{c}\text { Crude } \\
\text { odds ratio }\end{array}$ & $\begin{array}{l}95 \% \text { confidence } \\
\text { intervals }\end{array}$ & $\begin{array}{c}\text { Adjusted } \\
\text { odds ratio }\end{array}$ & $\begin{array}{l}95 \% \text { confidence } \\
\text { intervals }\end{array}$ \\
\hline \multicolumn{6}{|l|}{ Gender } \\
\hline & Female & 1 & & 1 & \\
\hline & Male & 1.59 & $1.33,1.90$ & 1.28 & $1.05,1.57$ \\
\hline \multicolumn{6}{|c|}{ Family structure } \\
\hline & Other & 1 & & & \\
\hline & Single & 1.17 & $0.72,1.89$ & 1.29 & $0.77,2.16$ \\
\hline & Married & 0.69 & $0.42,1.13$ & 0.83 & $0.49,1.40$ \\
\hline & Divorced & 0.67 & $0.32,1.38$ & 0.62 & $0.28,1.41$ \\
\hline & Separated & 1.19 & $0.72,1.96$ & 1.34 & $0.78,2.29$ \\
\hline & Widowed & 1.45 & $0.65,3.25$ & 1.2 & $0.49,2.96$ \\
\hline & Common law & 1.07 & $0.64,1.79$ & 1.29 & $0.75,2.23$ \\
\hline \multicolumn{6}{|c|}{ Parent paid attention to subject's school work } \\
\hline & Not at all & 1 & & 1 & \\
\hline & Very closely & 0.24 & $0.16,0.36$ & 0.34 & $0.22,0.52$ \\
\hline & Closely & 0.41 & $0.28,0.60$ & 0.49 & $0.32,0.99$ \\
\hline & Somewhat & 0.59 & $0.39,0.89$ & 0.63 & $0.41,0.99$ \\
\hline \multicolumn{6}{|c|}{ Parent controlled the time subject came in at night } \\
\hline & Never & 1 & & 1 & \\
\hline & Yes & 0.88 & $0.41,1.90$ & 1.45 & $0.63,3.36$ \\
\hline & No & 2.46 & $1.11,5.47$ & 2.74 & $1.16,6.67$ \\
\hline & Rarely & 2.43 & $1.10,5.35$ & 2.95 & $1.26,6.93$ \\
\hline \multicolumn{6}{|c|}{ Parent knew where subject was } \\
\hline & Always & 1 & & 1 & \\
\hline & Never & 5.12 & $3.27,8.03$ & 2.89 & $1.75,4.78$ \\
\hline & Sometimes & 2.38 & $1.94,2.91$ & 1.72 & $1.37,2.15$ \\
\hline \multicolumn{6}{|c|}{ Parent and subject discussed about danger of drugs } \\
\hline & No & 1 & & 1 & \\
\hline & Yes & 0.96 & $0.81,1.15$ & 1.17 & $0.96,1.43$ \\
\hline
\end{tabular}

12 months or over the past 30 days. Family structure did not predict marijuana use over the past 12 months or over the past 30 days. How closely parents paid attention to the adolescents' work at school did not show any significant association with the past-12-month use or the past-30-day use of marijuana among the subjects. Parents' control of the time the subjects came in at night did not predict either past-12-month or past-30-day use of marijuana among the subjects, similar to the pattern observed for parents and subjects discussing the dangers of drug abuse. Parents' knowledge of where the subjects were after school hours or on the weekends showed inconsistent patterns, with parents' never knowing the subjects' whereabouts showing no significant association with marijuana use over the past 12 months. However, it showed a significant association with marijuana use over the past 30 days. Nevertheless, only a very small proportion of the adolescents indicated that their parents never knew where they were.

\section{DISCUSSION}

Lifetime use of marijuana was found to be high in this study, which is similar to previous studies that found high prevalence of marijuana use among adolescents $(1,2,23)$. A significantly higher proportion of male than female adolescents reported lifetime use of marijuana. However, the proportions of male and female adolescents who had used marijuana in the past 12 months did not differ significantly. In contrast with the finding by Ledoux et al that significant gender differences existed among adolescents in their marijuana use within the past three months, this study found no significant differences in marijuana use in the past 30 days between male and female adolescents (3). The reasons for this pattern of 
Table 4: Factors associated with marijuana use over the past 12 months versus over the past 30 days among adolescents in Jamaica

\begin{tabular}{|c|c|c|c|c|c|}
\hline \multirow[b]{2}{*}{ Variables } & & \multicolumn{2}{|c|}{ Past 12 months } & \multicolumn{2}{|c|}{ Past 30 days } \\
\hline & & $\begin{array}{c}\text { Adjusted } \\
\text { odds ratio }\end{array}$ & $\begin{array}{l}95 \% \text { confidence } \\
\text { intervals }\end{array}$ & $\begin{array}{c}\text { Adjusted } \\
\text { odds ratio }\end{array}$ & $\begin{array}{c}95 \% \text { confidence } \\
\text { intervals }\end{array}$ \\
\hline \multicolumn{6}{|l|}{ Gender } \\
\hline & Female & 1 & & 1 & \\
\hline & Male & 1.24 & $0.91,1.69$ & 1.09 & $0.70,1.68$ \\
\hline \multicolumn{6}{|c|}{ Family structure } \\
\hline & Other & 1 & & & \\
\hline & Single & 1.14 & $0.54,2.39$ & 0.72 & $0.24,2.18$ \\
\hline & Married & 1.07 & $0.50,2.29$ & 1.01 & $0.32,3.20$ \\
\hline & Divorced & 1.12 & $0.36,3.52$ & 0.27 & $0.05,1.43$ \\
\hline & Separated & 0.89 & $0.41,1.95$ & 0.55 & $0.17,1.76$ \\
\hline & Widowed & 1.17 & $0.27,4.96$ & 1.17 & $0.12,11.49$ \\
\hline & Common law & 1.52 & $0.69,3.37$ & 1.12 & $0.34,3.72$ \\
\hline \multicolumn{6}{|c|}{ Parent paid attention to subject's school work } \\
\hline & Not at all & 1 & & 1 & \\
\hline & Very closely & 1.17 & $0.64,2.16$ & 2.18 & $0.90,5.23$ \\
\hline & Closely & 1.02 & $0.56,1.85$ & 2.35 & $0.98,5.59$ \\
\hline & Somewhat & 0.66 & $0.35,1.23$ & 1.28 & $0.51,3.19$ \\
\hline \multicolumn{6}{|c|}{ Parent controlled the time subject came in at night } \\
\hline & Never & 1 & & 1 & \\
\hline & Yes & 0.79 & $0.25,2.52$ & 4.1 & $0.42,40.37$ \\
\hline & No & 0.53 & $0.16,1.73$ & 3.69 & $0.36,37.51$ \\
\hline & Rarely & 0.43 & $0.13,1.41$ & 1.7 & $0.17,17.15$ \\
\hline \multicolumn{6}{|c|}{ Parent knew where subject was } \\
\hline & Always & 1 & & 1 & \\
\hline & Never & 0.62 & $0.31,1.24$ & 0.33 & $0.12,0.86$ \\
\hline & Sometimes & 0.61 & $0.44,0.84$ & 0.84 & $0.53,1.32$ \\
\hline \multicolumn{6}{|c|}{ Parent and subject discussed about danger of drugs } \\
\hline & No & 1 & & 1 & \\
\hline & Yes & 0.84 & $0.62,1.13$ & 0.65 & $0.43,1.00$ \\
\hline
\end{tabular}

marijuana use are unclear, but it is possible that more male than female adolescents initiate marijuana use. However, it does appear that, shortly after initiation, the pattern of consumption seemingly becomes similar for male and female adolescents, and apparently remains fairly constant over time. It may then be that this pattern persists and is carried through to adulthood. Indeed, Chambers et al posited that drug misuse patterns formed during adolescence may be carried through to adulthood (5). Thus, gender differences that disappear shortly after initiation of marijuana use result in a fairly consistently similar pattern of consumption. Intuitively, this pattern may be brought about by levelling off of decreases in the proportion of male adolescents who continue consumption of marijuana and, simultaneously, levelling off of increases in the proportion of female adolescents who initiate consumption. More investigation is needed to confirm this postulation.

For both male and female adolescents, previous studies found that the prevalence of their lifetime use of marijuana was higher than their marijuana use over the past one year (8). Additionally, this study found that gender was an independent predictor of lifetime use of marijuana, as being male was a risk factor for lifetime use of marijuana. This could be related to the social norms concerning masculine and feminine behaviour among adolescents: male adolescents might be allowed to go out more frequently, return when they wish and use marijuana, without social sanctions. However, why this difference between males and females in their risk of lifetime use of marijuana disappears soon (being male was not found to be a risk factor for marijuana use over 
the past 12 months and over the past 30 days) is difficult to explain.

Interestingly, significant differences were observed in the adolescents' lifetime use of marijuana by their family structure. However, it is important to note that the differences were not between families with two parents (married or in a common law marriage) versus families with one parent (single, divorced, separated or widowed). For example, families with married parents $(13.4 \%)$ and families with divorced parents $(13.9 \%)$ had very similar proportions of adolescents who reported lifetime use of marijuana, while the other family types had higher proportions of adolescents who reported lifetime use of marijuana. In other words, although there was a significant association between the type of family structure and lifetime use of marijuana by the adolescents, the observed association was not about two-parent families versus one-parent families. Importantly, however, in the multivariate regression model, this association was not observed. When other predictor variables were controlled for, none of the family structures was a risk factor or protective factor against lifetime use of marijuana. This sheds further light on the lack of a clear pattern of association between family structure and lifetime use of marijuana.

However, two predictor variables that assessed parents' control of adolescents' activities (namely, how closely parents paid attention to the subjects' work at school and whether parents controlled the time the subjects came in at night) were significantly associated with lifetime use of marijuana. Not surprisingly, parents who paid attention to the subjects' school work very closely, closely or even somewhat closely all minimized the risks of first-time use of marijuana among the adolescents. This is similar to the finding among adolescents in the USA, which showed that parental monitoring significantly lowered the risks of initiating marijuana (21). This suggests that what goes on while the adolescents are at school and how the adolescents perceive that their parents get involved in and/or monitor it will likely impact their decision to experiment with marijuana. Thus, it is likely that ensuring that students keep busy with academic and co-curricular activities at school may help keep them off drugs. However, the findings from this study suggested that once the adolescents had initiated marijuana use, parental monitoring of their activities apparently became less effective. This was because both variables that measured parental monitoring of adolescents' activities (how closely parents paid attention to the subjects' work at school and whether parents controlled the time the subjects came in at night) were found to be neither protective nor risk factors for marijuana use over the past 12 months and over the past 30 days. Whether parents had knowledge of the whereabouts of the adolescents after school hours and on the weekends had a significant association with lifetime use of marijuana. Adolescents whose parents never knew where they were after school hours or on the weekends had 5.12 times as high the risk of initiating marijuana use compared to adolescents whose parents always knew their whereabouts.

Parental communication with adolescents was not found to be a protective factor against marijuana use. This is consistent with the findings in a study of 9- to 18-year-olds in North Carolina, USA, which showed that parental communication with children about drugs was not protective against the commencement of marijuana use (22).

Marijuana use in the past 30 days connoted current use. In this study, marijuana use in the past 30 days among the adolescents was considerably lower than lifetime use. In Trinidad and Tobago, a study among secondary school students also reported a similar pattern with lifetime use being higher than current use (6). This pattern suggested that a high proportion of adolescents might begin to 'experiment' with the drug but might not continue its use. Experimentation with marijuana is used in this context to denote using the drug out of curiosity with a view to seeing how it will feel. Possible reasons for this are unknown but could be related to curiosity, peer pressure or experiencing adverse effects after first use. However, it is important to note that reductions in the proportions of adolescents who reported marijuana use in the past 12 months as well as in the past 30 days cut across all the family structures, with no significant differences among the family structures. Regarding risk factors for marijuana use over the past 12 months and over the past 30 days, neither family structure nor gender was a predictor.

Across patterns of marijuana use, the findings from this study were contrary to the findings that adolescents from one-parent families had higher risks of using hard drugs $(12,13)$. The findings from this study also contrast with those of Hemovich and Crano which suggested that adolescents from one-parent families were significantly more likely to use marijuana than their counterparts in two-parent families (14). So, what is it in the Jamaican society that levels off the risks of marijuana consumption among students from the various family structures, especially two-parent families versus one-parent families? 
It is important to understand the social organization of the Jamaican family system in order to gain insight into what possibly might explain the lack of significant differences in marijuana use among the adolescents from different family structures. While one-parent families are apparently dominant, Jamaicans have a strong extended family system. Within this system, parents (whether in one- or two-parent families) often live with an extended family member(s), who may be a grandmother, grandfather, uncle, aunt, sister, brother or other close relation. These relations normatively take part in the socialization of the younger members of the family. Therefore, their presence in the household apparently contributes to cushioning the psychosocial effects that the absence of a second parent (be it father or mother) might have. The extent to which this is effective is unknown.

The strength of this study lies in the use of data from a nationally representative sample to investigate the association between the various family structures inherent in Jamaica and the use of marijuana by adolescents. It attempts to provide insights into the effects that family structure, gender and parental monitoring of the social activities of the adolescents had on the patterns of marijuana use. The key limitation is that data were not collected based on family structures that classified one-parent families into mother-only families and father-only families versus families with two biological parents and families with one biological parent and one step-parent. This distinction is apparently important given the arguments in some studies or reports that children from mother-only families tend to have higher risks of using drugs (15).

\section{CONCLUSION}

Lifetime use of marijuana among adolescents in Jamaica was high, and was associated with family structure but not from the perspective of one-parent families versus two-parent families. Marijuana use over the past one year and marijuana use over the past 30 days were not associated with family structure. Parents who paid very close attention to adolescents' school activities was a protective factor against lifetime use of marijuana, as were parents who paid close attention or even somewhat close attention. However, once adolescents had initiated marijuana use, parental attention to their school work became less effective in minimizing their risk of marijuana consumption. Parents' never knowing the whereabouts of the adolescents was a risk factor for their commencing marijuana use.
These findings are important for programmes aimed at reducing marijuana use among adolescents. Such programmes should be inclusive of adolescents from all family structures, rather than focussing on adolescents from a particular family structure on the assumption that these adolescents have higher risks of marijuana use as reported in other countries. Such programmes should also promote more involvement of parents in the activities of their children while in school and after school hours.

\section{REFERENCES}

1. Hall WD. Cannabis use and the mental health of young people. Aust $N$ Z J Psychiatry 2006; 40: 105-13.

2. Ramo DE, Liu H, Prochaska JJ. Tobacco and marijuana use among adolescents and young adults: a systematic review of their co-use. Clin Psychol Rev 2012; 32: 105-21.

3. Ledoux S, Miller P, Choquet M, Plant M. Family structure, parent-child relationships, and alcohol and other drug use among teenagers in France and the United Kingdom. Alcohol Alcohol 2002; 37: 52-60.

4. Inter-American Drug Abuse Control Commission (CICAD), Secretariat for Multidimensional Security (SMS), Organization of American States (OAS). Comparative analysis of student drug use in the Caribbean countries: Antigua and Barbuda, Barbados, Dominica, Grenada, Guyana, Haiti, Jamaica, St Kitts and Nevis, St Lucia, St Vincent and the Grenadines, Trinidad and Tobago and Suriname. A report on student drug use in 12 Caribbean countries. Washington, DC: CICAD, SMS, OAS; 2010. Available from: http://www.cicad.oas.org/Main/pubs/ StudentDrugUse-Caribbean2011.pdf.

5. Chambers RA, Taylor JR, Potenza M. Developmental neurocircuitry of motivation in adolescence: a critical period of addiction vulnerability. Am J Psychiatry 2003; 160: 1041-52.

6. Maharajh HD, Konings M. Cannabis and suicidal behaviour among adolescents: a pilot study from Trinidad. ScientificWorldJournal 2005; 5: 576-85.

7. National Council on Drug Abuse, Jamaica. National secondary school survey 2006. Washington, DC, United States of America: InterAmerican Drug Abuse Control Commission, Organization of American States.

8. Serafini G, Pompili M, Innamorati M, Temple EC, Amore M, Borgwardt $\mathrm{S}$ et al. The association between cannabis use, mental illness, and suicidal behavior: what is the role of hopelessness? Front Psychiatry 2013; 4: $1-5$.

9. Atkinson U, Abel WD, Whitehorne-Smith P. Current trends in adolescent substance use in Jamaica. WIMJ Open 2015; 2: 15-8.

10. Dhanookdhary AM, Gomez AM, Khan R, Lall A, Murray D, Prabhu $\mathrm{D}$ et al. Substance use among university students at the St Augustine campus of The University of the West Indies. West Indian Med J 2010; 59: 641-9.

11. National Council on Drug Abuse. National Secondary School Survey 2013. Fact Sheet. Kingston: National Council on Drug Abuse. Available from: http://ncda.org.jm/images/pdf/nss_2014_fact\%20sheet.pdf.

12. Weitoft GR, Hjern A, Haglund B, Rosen M. Mortality, severe morbidity, and injury in children living with single parents in Sweden: a population-based study. Lancet 2003; 361: 289-95.

13. Amato PR, Patterson SE. Single-parent households and mortality among children and youth. Social Science Research 2017; 63: 253-62.

14. Hemovich V, Crano WD. Family structure and adolescent drug use: an exploration of single-parent families. Subst Use Misuse 2009; 44: 2099-113.

15. Mather M. US children in single-mother families. Population Reference Bureau Data Brief. 2010. Accessed March 8, 2017. Available from: http://www.prb.org/pdf10/single-motherfamilies.pdf. 
16. Phythian K, Keane C, Krull C. Family structure and parental behavior: identifying the sources of adolescent self-control. Western Criminology Review 2008; 9: 73-87.

17. Haimi M, Lerner A. The impact of parental separation and divorce on the health status of children, and the ways to improve it. J Clin Med Genomics 2016; 4: 137.

18. Thomas DA. Confronting suicide: helping teens at risk. Second edition. Kingston, Jamaica: Choose Life Publishers; 2010.

19. Planning Institute of Jamaica. Jamaica - survey of living conditions 1996. Kingston, Jamaica: Planning Institute of Jamaica.
20. Hill K. Too many single parents. The Gleaner. April 10, 2011. Accessed December 2, 2016. Available from: http://jamaica-gleaner.com/glean$\mathrm{er} / 20110410 /$ news/news5.html.

21. Bohnert KM, Anthony JC, Breslau N. Parental monitoring at age 11 and subsequent onset of cannabis use up to age 17: results from a prospective study. J Stud Alcohol Drugs 2012; 73: 173-7.

22. Nonnemaker JM, Silber-Ashley O, Farrelly MC, Dench D. Parent-child communication and marijuana initiation: evidence using discrete-time survival analysis. Addict Behav 2012; 37: 1342-8.

23. Hall W, Degenhardt L. Adverse health effects of non-medical cannabis use. Lancet 2009; 374: 1383-91. 